\title{
Decoding fingerprints: elemental composition of vertebrae correlates to age-related habitat use in two morphologically similar sharks
}

\author{
Bree J. Tillett ${ }^{1,2,5, *}$, Mark G. Meekan ${ }^{4}$, David Parry ${ }^{3,5}$, Niels Munksgaard ${ }^{3}$, \\ Iain C. Field ${ }^{1,6}$, Dean Thorburn ${ }^{7}$, Corey J. A. Bradshaw ${ }^{8,9}$ \\ ${ }^{1}$ School for Environmental Research, ${ }^{2}$ Tropical Rivers and Coastal Knowledge Research Hub, \\ and ${ }^{3}$ School of Environment and Life Sciences, Charles Darwin University, Northern Territory 0810, Australia \\ ${ }^{4}$ Australian Institute of Marine Science, UWA Oceans Institute (MO 96), 35 Stirling Highway, \\ Crawley, Western Australia 6009, Australia \\ ${ }^{5}$ Australian Institute of Marine Science, Arafura Timor Research Facility, Northern Territory 0810, Australia \\ ${ }^{6}$ Graduate School of the Environment, Macquarie University, New South Wales 2109, Australia \\ ${ }^{7}$ Indo-Pacific Environmental, Mount Hawthorn, Western Australia 6010, Australia \\ ${ }^{8}$ The Environment Institute and School of Earth and Environmental Sciences, The University of Adelaide, Adelaide, \\ South Australia 5005, Australia \\ ${ }^{9}$ South Australian Research and Development Institute, PO Box 120, Henley Beach, South Australia 5022, Australia
}

\begin{abstract}
We compare vertebral microchemistry with previously described age-related movement patterns of bull sharks Carcharhinus leucas and pig-eye sharks C. amboinensis within coastal waters of north Australia. Laser ablation inductively coupled plasma mass spectrometry (LA-ICP-MS) quantified the chemical signatures of nursery habitats within the vertebrae of juvenile and adult sharks. We examined evidence for adults returning to these habitats by applying LA-ICP-MS along a growth axis of their vertebrae. We transposed chemical signatures with growth increments in adult vertebrae to correlate with age estimates. Unique elemental signatures were identified in each of the freshwater nurseries, but we did not find them in adult vertebrae. Age-specific changes in vertebral microchemistry in mature female bull sharks correlate with periodic returns every 1 to 2 yr to less saline environments to pup. We were unable to discriminate among natal habitats of pig-eye sharks using elemental fingerprints, and age-specific changes in vertebral microchemistry were also absent. We conclude that changes in vertebral microchemistry correlate with known habitat use patterns of the bull and pig-eye sharks, showing the potential of vertebral microchemistry to discern movement patterns in sharks.
\end{abstract}

KEY WORDS: Vertebral microchemistry · LA-ICP-MS · Movement · Long-term · Resource partitioning $\cdot$ Carcharhinidae

\section{INTRODUCTION}

The persistence of sharks as apex predators in marine environments is threatened by over-exploitation and habitat change (Myers et al. 2007, Field et al. 2009). Their $K$-selected life history means that they have reduced resilience to rapid change and are likely to be slow to recover from population decline
(Schindler et al. 2002). Effective management and conservation of these vulnerable predators is hindered by poor knowledge of movement patterns (Speed et al. 2010). This information is essential because it can identify key habitats (e.g. pupping areas, nurseries) within distribution ranges and helps define the ecological role of species. Additionally, it can identify evolved behaviours such as natal and pupping site fidelity (sensu 
Speed et al. 2010) that are critical to the maintenance of genetic diversity and replenishment of populations (Hueter et al. 2005).

Studies tracking shark movements and identifying patterns of habitat use in coastal regions typically involve tagging with standard (numerical), satellite or sonar tags (Speed et al. 2010). Such an approach is often logistically difficult and expensive because it first involves the capture, tagging and release (in good condition) of the shark. Furthermore, the animals must either be recaptured (standard tags), or tags must report to satellites or arrays of listening stations (sonar tags) for data acquisition (Voegeli et al. 2001, Simpfendorfer \& Heupel 2004). Rates of recapture are usually low, while failure of expensive satellite tags to report is commonplace (Hays et al. 2007). Arrays of listening stations require considerable effort to deploy, download and maintain, which can limit the duration and spatial extent of a study using this approach. Despite these problems, studies using these techniques have mapped fine-scale $(25 \mathrm{~km})$ movements of different-age cohorts of sharks in shallow coastal waters (Simpfendorfer et al. 2005, Heupel \& Simpfendorfer 2008, Yeiser et al. 2008, Heithaus et al. 2009, Ortega et al. 2009, Heupel et al. 2010), but the logistics, cost and limited life span of tags have restricted the number of target individuals and species and, in the case of sonar tags, the spatial extent of the sampling area.

To overcome the limitations associated with conventional tracking, natural chemical fingerprints are a developing tool to trace age-related movements of sharks among habitats throughout their lifetime. This method is similar to tracking fish movements based on otolith microchemistry. Environmental signatures ('fingerprints') stem from either pollution or natural leaching and weathering of elements from the Earth's crust into aquatic systems (Campana 1999, Gillanders 2005, Speed et al. 2010). As individuals living and growing in these environments osmoregulate, trace elements are absorbed across the skin and gills and can either be substituted for calcium or trapped within protein matrices of hard structures such as otoliths or vertebrae (Gillanders \& Kingsford 2000, Dean \& Summers 2006, Hale et al. 2006). In otoliths, elements are deposited in concentrations reflecting that of the aquatic environment and can be influenced by the physical properties of that medium (Gillanders \& Kingsford 2000, Walther \& Thorrold 2006, Brown \& Severin 2009). For example, strontium (Sr) typically has high concentrations and is uniform in marine environments, while barium (Ba) shows the opposite pattern and is enriched in freshwater or during flood periods in the low salinity region of freshwater plumes (McCulloch et al. 2005, Crook \& Gillanders 2006). Concentrations of elements in marine environments reflect proximity to freshwater inputs or nutrient upwellings, with trace element:Ca ratios typically higher in less saline waters (Beamish et al. 2005, Kingsford et al. 2009). Correlating mineralisation with growth increments within these structures enables age-based interpretation of records that can be used to describe the periodicity of habitat use (Gillanders \& Kingsford 2000, McCulloch et al. 2005).

We apply similar principles as a baseline approach to investigate whether changes in vertebral microchemistry correlate with known age-specific changes in habitat use of bull sharks Carcharhinus leucas and pigeye sharks C. amboinensis. Both of these species are large apex predators (3400 and $2800 \mathrm{~mm}$ maximum total length in Australia, respectively) within shallow waters of tropical and subtropical coasts (Last \& Stevens 2009). Pop-up satellite tags have confirmed the affinity of large bull sharks to shallow coastal environments and tracked a few individuals embarking on long-distance movements $(1506 \mathrm{~km})$ (Brunnschweiler et al. 2010, Carlson et al. 2010). Bull sharks use freshwater nurseries with juveniles remaining in these areas for approximately $4 \mathrm{yr}$ (Thorburn \& Rowland 2008, Heupel et al. 2010). Preliminary genetic assessment suggests female pupping site fidelity, although it is unclear how frequently females return to pup and whether males also return, in which case mating as well as pupping might occur in freshwater (Tillett et al. 2011b). Short-term tracking research ( 1.5 yr) has suggested that habitat use is defined by maturity (Simpfendorfer et al. 2005, Heupel \& Simpfendorfer 2008, Yeiser et al. 2008, Heupel et al. 2010). Conversely, adult pig-eye sharks do not show this pattern; rather, population genetic structure suggests restricted movement (Tillett et al. unpubl.). Acoustic tracking studies indicate age-based partitioning of habitat, with juveniles of this species occupying areas adjacent to creek and river mouths (Last \& Stevens 2009, Knip et al. 2011).

We hypothesise that periodic chemical signatures of freshwater (indicated by low Sr:Ba ratios for bull sharks) or low-salinity environments (indicated by declines in element:Ca ratios for pig-eye sharks) will occur in vertebrae of adults, indicating returns to nurseries. These should be more evident in females because they return regularly to pup in freshwater or estuarine nurseries. If there is natal site fidelity occurring in these sharks, the chemical signatures from adult birth bands should be similar to those deposited in the vertebrae when they return to the same freshwater or estuarine nursery to pup. Second, we hypothesise that chemical signatures will change post-maturity coinciding with changes in habitat use. Third, Sr:Ba ratios should differ in young juvenile stages (inner $150 \mathrm{~mm}$ of the vertebra) of bull and pig-eye sharks because the former use freshwater nurseries while the 
latter use nurseries in shallow coastal areas. As sharks grow and leave these nurseries, ratios should be increasingly similar between the species because of greater habitat overlap. Ultimately, post-maturity ratios should also be similar because both species are found in deeper coastal water (approximately $20 \mathrm{~m}$ ) as adults.

\section{MATERIALS AND METHODS}

Vertebrae collection. We removed 10 to 15 thoracic vertebrae from 88 pig-eye (39 adults, 49 juveniles) and 92 bull sharks (18 adults and 74 juveniles). Adult sharks were collected by scientific observers working with the Northern Shark Fishery operating along the Northern Territory coastline in 2009. In this fishery, long-lines must not exceed 15 nautical miles and have no more than 1000 snoods (hooks), and nets must be 1000 to $2500 \mathrm{~m}$ long with a square mesh size of 150 to $250 \mathrm{~mm}$ and a drop of 50 to 100 meshes. We obtained juvenile sharks from both commercial fisheries and our field work from 2002 to 2009. Fishery-independent studies were done using long-lines approximately $50 \mathrm{~m}$ long with 50 snoods (size 11/0) positioned $1 \mathrm{~m}$ apart, and nets approximately $50 \mathrm{~m}$ long with a square mesh size of 150 to $250 \mathrm{~mm}$ with a 16-mesh drop. Both were weighted and deployed along the bottom in depths ranging from 5 to $15 \mathrm{~m}$. We collected juvenile pig-eye sharks from inshore coastal waters around Broome, Western Australia, from the northeastern side of the Joseph Bonaparte Gulf to the Gulf of Carpentaria, Northern Territory, and from Townsville, Queensland (Fig. 1). We collected juvenile bull sharks from 6 different northern Australian river systems: the Liverpool, Roper, Towns, Fitzroy, Daly and East Alligator Rivers (Fig. 1). Sample sizes, sex ratio and capture dates from each location are supplied in Table S1 in the supplement at www.int-res.com/articles/suppl/ m434p133_supp.pdf. We measured sex, total weight (TW) total length (TL) and fork length (FL) when possible. We inspected small individuals $(<1 \mathrm{~m}$ TL) for the presence of umbilical scars as an indication of time since birth. Once thoracic vertebrae were removed, we stored them frozen or temporarily immersed them in $5 \%$ sodium hypochlorite solution before storing dry. Due to the morphological similarities between members of the genus Carcharhinus, we collected a small tissue fragment $(\sim 1 \mathrm{~g})$ from each individual and genetically tested it to confirm species identification (Tillet et al. 2011b, Tillett et al. unpubl.).

Preparation of vertebrae. We defrosted frozen samples and excised excess tissue, neural and haemal arches to expose the centra. We separated individual

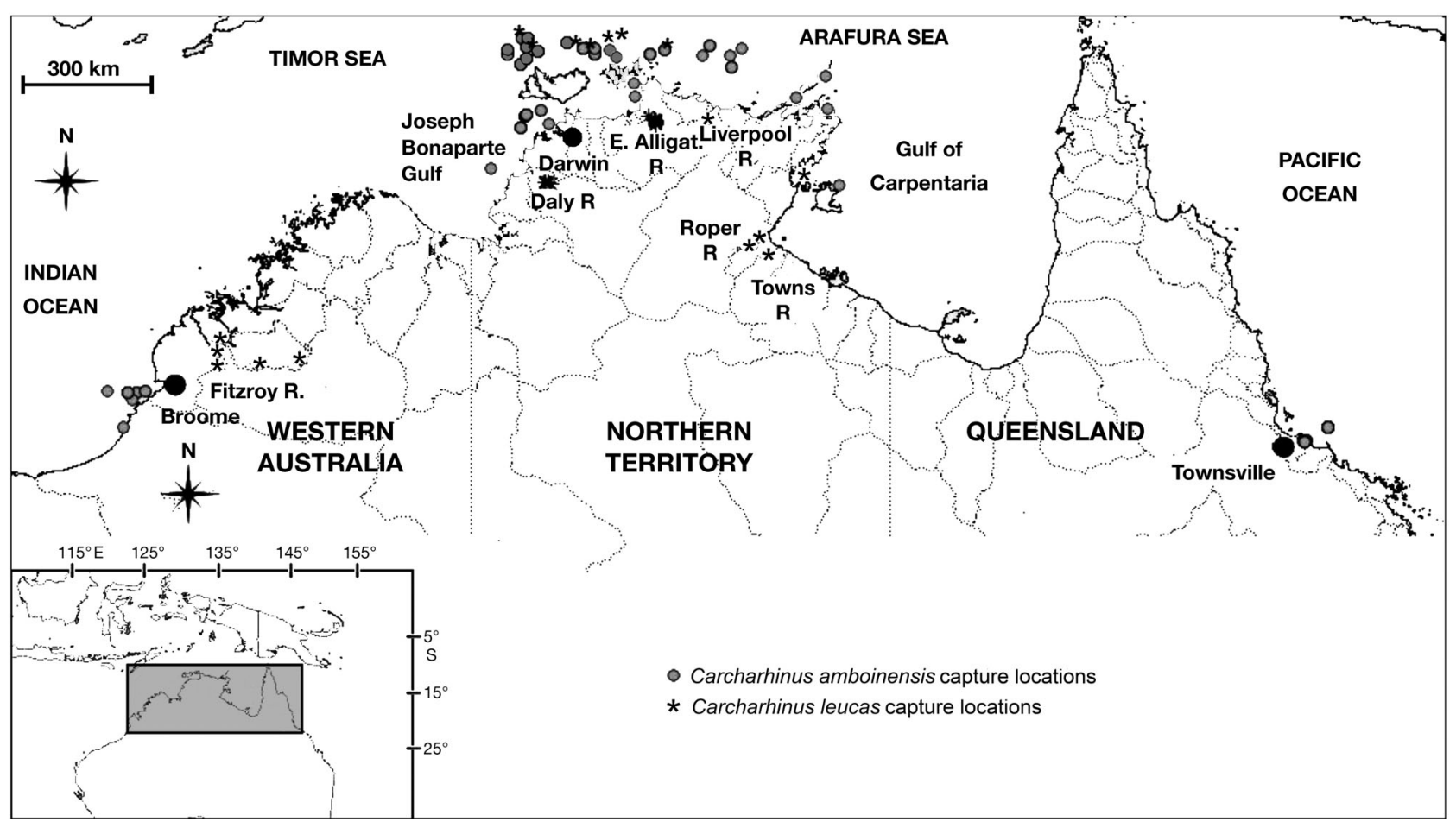

Fig. 1. Capture locations for pig-eye sharks Carcharhinus amboinensis (total $\mathrm{n}=88$; 39 adults, 49 juveniles) and bull sharks Carcharhinus leucas (total $\mathrm{n}=92 ; 18$ adults, 74 juveniles) across northern Australia 
centra and removed any connective tissue with a scalpel blade or abrasive material. We subsequently washed centra in Milli-Q water and left polished centra to air-dry in a fume hood causing any remaining tissue to become brittle and peel away. We immersed remaining vertebrae (74 juvenile bull and 16 juvenile pig-eye sharks) in $5 \%$ sodium hypochlorite solution for approximately $1 \mathrm{~min}$ or until remaining flesh had been removed. Again, we excised neural and haemal arches to expose the centra. We weighed all cleaned vertebrae and embedded them whole in a 2-part casting-laminating epoxy resin (Barnes), through which we sectioned using a low-speed IsoMet diamond saw at approximately $240 \mathrm{rpm}$ with a $250 \mathrm{~g}$ load weight. We ground sections on wet and dry paper until $\sim 0.5 \mathrm{~mm}$ thick and rinsed again in Milli-Q water to remove potential contaminants (i.e. the outer edge potentially containing absorbed resin was removed). We mounted sections on glass slides using either Crystalbond ${ }^{\mathrm{TM}}$ 509 (ProSciTech, ) or with a temporary adhesive (Blu-Tack, Bostik) and took care not to contaminate vertebral regions to be ablated. We viewed sections under a Leica DM 400B compound microscope and marked the desired starting position for each analysis by a small incision in the surrounding resin.

Ageing. We viewed vertebral sections using the imaging software package OPTIMAS 6.5 (Media Cybernetics) and aged by counting growth bands (defined as one opaque and one translucent ring) visible along the corpus calcareum reading from the focus to the outer centrum edge (Fig. 2) (Campana 2001). We regarded the change of angle caused by differences in growth rate from intra-uterine to post-natal life history stages as the point of birth, or birth mark and recorded it as year zero (Cailliet \& Goldman 2004). Annual growth band deposition has been confirmed for bull sharks (Branstetter \& Stiles 1987, Neer et al. 2005) and pig-eye sharks (Tillett et al. 2011a).

Preliminary study. Initial analyses determined (1) the concentric manner in which the calcareous vertebral matrix was deposited and the corresponding 3-dimensional structure of the sagittal section, and (2) inter-vertebral variation in chemical composition of the matrix. We also tested to see whether temporary bleaching to remove excess tissue resulted in the leaching of elements from the vertebral matrix. For this analysis, we removed 4 thoracic vertebrae from 2 individuals of each species. After air drying, we removed excess connective tissue by trimming ( 2 vertebrae) or bleaching ( 2 vertebrae). We then set all 4 vertebrae in resin, sectioned and mounted them on slides as described above. We analysed chemical compositions to compare effects of treatments.

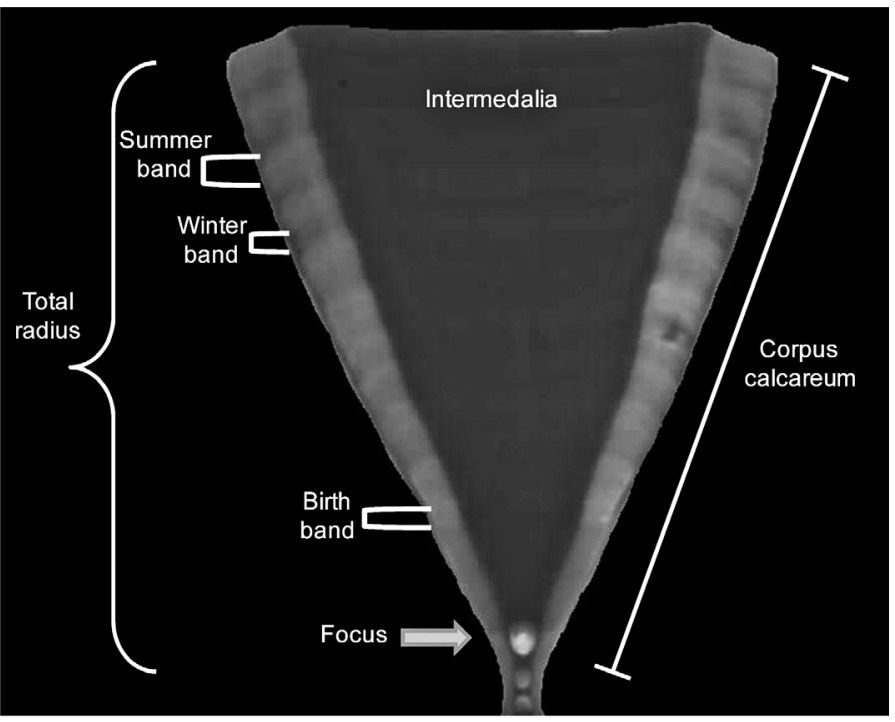

Fig. 2. Carcharhinus leucas. Sagittal section of bull shark vertebrae (aged 10 yr) displaying annual growth increments, and descriptions of vertebral attributes

Laser ablation inductively coupled plasma mass spectrometry (LA-ICP-MS). We analysed samples using a 213-nm laser (Nd:YAG, 5th harmonic; NewWave Research UP-213) coupled to an inductively coupled plasma mass spectrometer (Agilent 7500ce) connected to a Hitachi camera. Analyses were performed at Charles Darwin University, Darwin, Northern Territory, Australia. We optimised the LA-ICP-MS for maximum sensitivity by adjusting $\mathrm{He}$ and Ar flows and plasma power during ablation of the National Institute of Standards and Technology (NIST) 612 glass standard. We monitored oxide formation by the $\mathrm{ThO}^{+}: \mathrm{Th}^{+}$ ratio which was typically $<0.5 \%$. We monitored instrumental drift by ablating the NIST 612 glass standard after ablating 7 shark samples. If variation between NIST 612 glass standard was greater than 5\%, we retested the shark samples.

Prior to activation of the laser, we recorded elemental composition of the blank sample gas for $20 \mathrm{~s}$. We made initial measurements of 13 elements $\left({ }^{7} \mathrm{Li},{ }^{25} \mathrm{Mg}\right.$, ${ }^{27} \mathrm{Al},{ }^{31} \mathrm{P},{ }^{43} \mathrm{Ca},{ }^{55} \mathrm{Mn},{ }^{54} \mathrm{Fe},{ }^{63} \mathrm{Cu},{ }^{64} \mathrm{Zn},{ }^{86} \mathrm{Sr},{ }^{139} \mathrm{La}_{,}{ }^{137} \mathrm{Ba}$ and ${ }^{238} \mathrm{U}$ ) that vary in concentration in otoliths among different aquatic environments, but are not linked to diet (Milton \& Chenery 2001, Cailliet \& Goldman 2004, Kraus \& Secor 2004, Martin \& Thorrold 2005, Brown \& Severin 2009). We can only assume that these same elements are equally unaffected by diet when isolated from vertebral tissues. From this list, we omitted from further analysis those elements that were not recorded consistently above detection limits (calculated as 3 times the standard deviation of the blank signal). Further analysis considered 6 elements $\left({ }^{7} \mathrm{Li},{ }^{25} \mathrm{Mg},{ }^{55} \mathrm{Mn}\right.$, 
${ }^{86} \mathrm{Sr},{ }^{64} \mathrm{Zn}$ and ${ }^{137} \mathrm{Ba}$ ) that were all well above detection limits calculated using the LA-ICP-MS software Glitter (Van Achterbergh et al. 2001) (0.006, 0.069, 0.070,

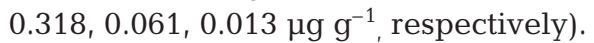

For both species, we quantified elemental signatures of nursery areas by spot analyses of the later region of the first 6-mo period (typically translucent) of the birth band (see above, Fig. 2) of the sectioned vertebrae of juveniles (up to $850 \mathrm{~mm} \mathrm{TL}$, Last \& Stevens 2009). We investigated age-related habitat use and the return to natal environments by ablating along the growth axis of the corpus calcareum (referred to as 'line scans') within the vertebrae initiating from the birth band, moving across annual growth increments towards the distal edge of the section (Fig. 2) on mature individuals (>2200 mm TL). We pre-ablated line scans to remove potential surface contaminants.

Analysis. Scanning electron microscopy (SEM) with X-ray Energy Dispersive Spectrometry (EDS) of 2 vertebral sections from each shark species confirmed constant percent composition of Ca (35\%) throughout the vertebrae, allowing use of this element as an internal reference standard (see Fig. S1 and Table S2 in the supplement) in LA-ICP-MS. This, combined with the reference silicate glass (NIST-612) as an external calibration standard within each analytical session, enabled the conversion of elemental count rates into concentrations (ppm) using the data-processing software Glitter (Van Achterbergh et al. 2001). NIST glasses have been used as a calibration standard for the analysis of carbonates and calcified teleost otoliths (Munksgaard et al. 2004, Hale et al. 2006, Steer et al. 2009). Glitter's data reduction accommodates gas blank corrections. The vertical homogeneity (signature does not change with depth through the section) of the sections enabled the user-selectable 'quantitation' window to quantify only the part of the analysis where the analyte signals were stable, thus eliminating potential contaminants ablated with surface material. We checked all analytical spectra for non-target signals represented by the rapid decline in ${ }^{43} \mathrm{Ca}$ count rate. The variation in analyte concentrations of the NSIT 612 standards remained within acceptable limits $( \pm 5 \%)$ within each analytical session.

We compared the chemical signature for each nursery using Euclidean-distance similarity matrices of standardised elemental concentrations. We evaluated the evidence for differences between signatures using analysis of similarity (ANOSIM) which uses permutations to determine if the assigned groups are more similar in composition than samples from other groups (Chapman \& Underwood 1999, Clarke \& Gorley 2001). ANOSIM generates an $R$-statistic which indicates the magnitude of difference among groups and ranges from -1 to 1 . A value of ' 0 ' indicates that there is no dif- ference between groups and '1' that the groups differ completely. Statistical evidence for differences due to unique environmental signatures is determined by comparing the sample $R$ grouped by nurseries with those produced by randomly assigning samples to groups. The portion of random arrangements with $R$-values greater than the sample gives the probability of observed patterns arising at random. Similarity percentages (SIMPER) then determined which elements differed between nursery signatures by calculating the average distance (based on Euclidean distance) within and between all nurseries estimating the percent contribution of each element to the overall distance (PRIMER-E). We screened data for the presence of outliers and conformity with multivariate normality, and removed those identified.

Analysis of line scans using Glitter provides an average composition of the selected scan (or portion of scan), but does not quantify spatial variation within the selected scan. Therefore, we transformed the analyte count data from each ICP-MS replicate into net count rates relative to net count rates for the internal standard $(\mathrm{Ca})$ and transposed these ratios as a function of the ablated line scan distance using a customised Excel $^{\mathrm{TM}}$ spreadsheet. We smoothed the data using a running median and average calculation of 8 ICP-MS replicates (equivalent to a scan distance of $35 \mu \mathrm{m}$ ) (Munksgaard et al. 2004). We correlated chemical signatures with growth increments to identify agespecific movement patterns. We looked for evidence of periodic movements of adults into nurseries shown by declines in $\mathrm{Sr}: \mathrm{Ba}$ ratios (indicating time spent in marine/freshwater habitats for bull sharks) and reductions in element:Ca ratios (indicating time spent in offshore/onshore habitats for pig-eye sharks). Inter-specific Sr:Ba net counts per second (cps) ratios were also compared to infer different salinities of environments occupied within an individual's lifetime (McCulloch et al. 2005, Clarke et al. 2009). We used Glitter's 'quantitation' window to select birth bands and sections in the line scan analysis that might indicate return movements by adults into nursery environments. We compared similarity in multi-elemental composition between these returns and both juvenile signatures within adult vertebrae and nurseries identified from juvenile spot analysis using ANOSIM and principal component analysis (PCA).

\section{RESULTS}

Elemental composition was consistent between spot analyses of same age sections of the corpus calcareum within vertebrae confirming the concentric growth of vertebrae (Global $R=0.095, \mathrm{p}=0.251$; Global $R=$ 
$0.067, \mathrm{p}=0.345$ for pig-eye and bull sharks, respectively). Similarly, elemental composition of spot analysis of the same age sections of the corpus calcareum was consistent between vertebrae, confirming intervertebral mineralisation was also constant (Global $R=$ $0.058, \mathrm{p}=0.222$; Global $R=0.086, \mathrm{p}=0.191$ for pig-eye and bull sharks, respectively). Bleaching vertebrae to remove connective tissue did not cause leaching of elements from the vertebral matrix, supported by similar elemental composition of spot analysis between same-age sections of vertebrae treated differently to remove connective tissue (Global $R=0.039, \mathrm{p}=0.296$; Global $R=0.009, \mathrm{p}=0.378$ for pig-eye and bull sharks, respectively).

SIMPER of spot analyses on juvenile bull shark vertebrae quantified the percent contribution of each element to nursery signatures. The contribution of each element to these signatures differed between nurseries (Fig. 3). Barium $\left({ }^{137} \mathrm{Ba}\right.$ ) was characteristic in the Liverpool River and almost absent from the East Alligator and Towns Rivers signatures. Lithium $\left({ }^{7} \mathrm{Li}\right)$ and Strontium $\left({ }^{86} \mathrm{Sr}\right)$ contributed similarity to signatures in all locations except the Liverpool River. ANOSIM confirmed differences (indicated by Euclidean distances) between nurseries were due to environmental signatures rather than randomly generated (Overall global $R$ $=0.373, \mathrm{p}=0.0001$; Table 1).

Bull sharks displayed large shifts in vertebral microchemistry with age (Fig. 4). Juvenile Sr:Ba net cps ratios differed among individuals and ranged from $<100$ to 300. Ratios either remained constant or steadily increased (to 300-700) until maturity (8 to 10 yr). Mature females $(n=14)$ showed cyclic declines in Sr:Ba ratios (every 1 to 2 yr) (Fig. 4a), possibly indicating a periodic return to breeding grounds (marked by spots in Fig. 4a). Cyclic patterns were less distinct in male conspecifics $(\mathrm{n}=2)$ because declines in these individuals were predominately within the $5 \%$ variation attributable to instrument drift (Fig. 4b). Males also increased in $\mathrm{Sr}$ :Ba net cps ratios at younger ages ( 6 to $8 \mathrm{yr}$ ) than females ( 8 to $10 \mathrm{yr}$ ). Birth bands for adult bull sharks, irrespective of sex, did not group with any of the identified nurseries return periods. They were more similar to other adult birth bands than to any nursery defined from juvenile bull sharks (Table 2, Fig. S4 in the supplement).

In contrast to bull sharks, pig-eye nurseries could not be distinguished based on unique multi-elemental fingerprints (Global $R=0.109, \mathrm{p}=0.084$; Table 3 ; Fig. 5). SIMPER analyses showed manganese $\left({ }^{55} \mathrm{Mn}\right)$ as being most characteristic in Western Aus-

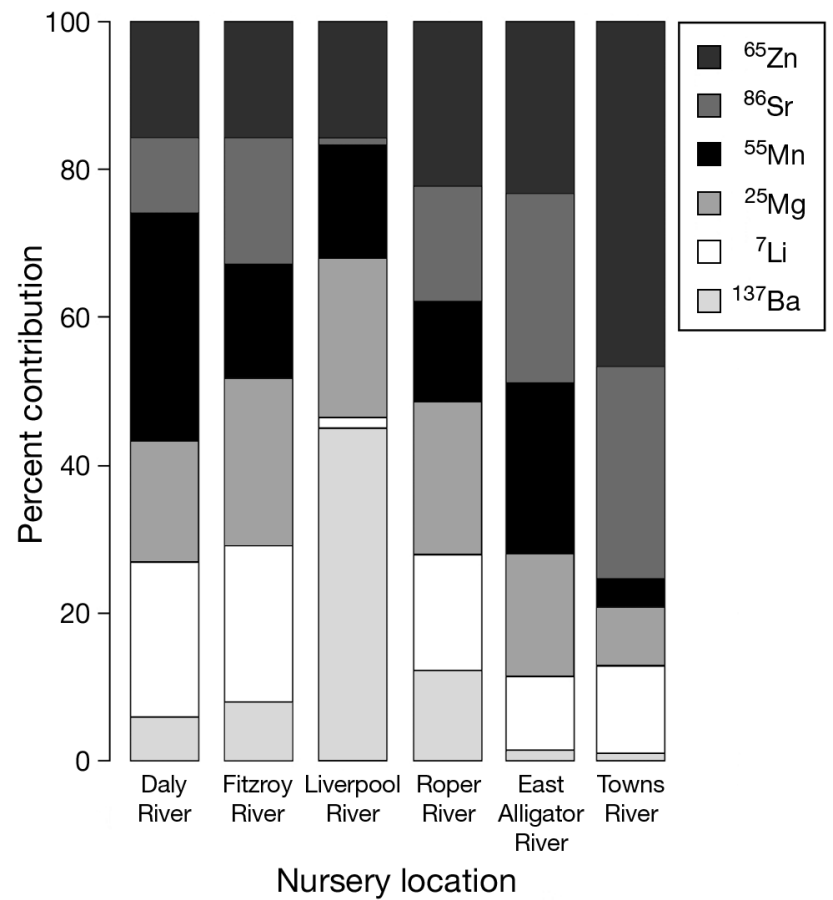

Fig. 3. Carcharhinus leucas. Similarity percentages (SIMPER) showing element contributions to bull shark nursery signatures. Total $\mathrm{n}=74$ (Fitzroy River: $\mathrm{n}=16$, Daly River: $\mathrm{n}=15$, Liverpool River: $\mathrm{n}=7$, East Alligator River: $\mathrm{n}=14$, Roper River: $\mathrm{n}=11$, Towns River: $\mathrm{n}=11$ )

tralia and least in the Northern Territory. Magnesium $\left({ }^{25} \mathrm{Mg}\right)$ was also a major component of elemental signatures in Western Australia, making least contribution in north Queensland. Barium $\left({ }^{137} \mathrm{Ba}\right)$ showed a complementary pattern, being most characteristic in north Queensland and least in Western Australia signatures.

Age-based differences in vertebral microchemistry were not evident in pig-eye sharks. Sr:Ba net cps ratios of juveniles were less variable than those of bull sharks and ranged between 200 and 450 (see Fig. S2 in the supplement). These values remained relatively constant with the onset of maturity. Any changes in Sr:Ba

Table 1. Carcharhinus leucas. Pairwise ANOSIM correlations among bull shark nurseries indicating whether differences are due to distinct environmental signatures or random factors. $R$-values ranging from $\sim 0$ (no difference) to 1 (highly different) are above the diagonal; p-values indicating the probability of differences arising purely at random are below the diagonal

\begin{tabular}{|lcccccc|}
\hline & $\begin{array}{c}\text { Fitzroy } \\
(\mathrm{n}=16)\end{array}$ & $\begin{array}{c}\text { Daly } \\
(\mathrm{n}=15)\end{array}$ & $\begin{array}{c}\text { Liverpool } \\
(\mathrm{n}=7)\end{array}$ & $\begin{array}{c}\text { East Alligator } \\
(\mathrm{n}=14)\end{array}$ & $\begin{array}{c}\text { Roper } \\
(\mathrm{n}=11)\end{array}$ & $\begin{array}{c}\text { Towns } \\
(\mathrm{n}=11)\end{array}$ \\
\hline Fitzroy & - & 0.374 & 0.306 & 0.296 & 0.191 & 0.358 \\
Daly & 0.0001 & - & 0.61 & 0.475 & 0.252 & 0.389 \\
Liverpool & 0.0110 & 0.0001 & - & 0.529 & 0.58 & 0.495 \\
East Alligator & 0.0003 & 0.0001 & 0.0003 & - & 0.438 & 0.473 \\
Roper & 0.0090 & 0.0030 & 0.0002 & 0.0001 & - & 0.528 \\
Towns & 0.0007 & 0.0003 & 0.0007 & 0.0001 & 0.0001 & - \\
\hline
\end{tabular}




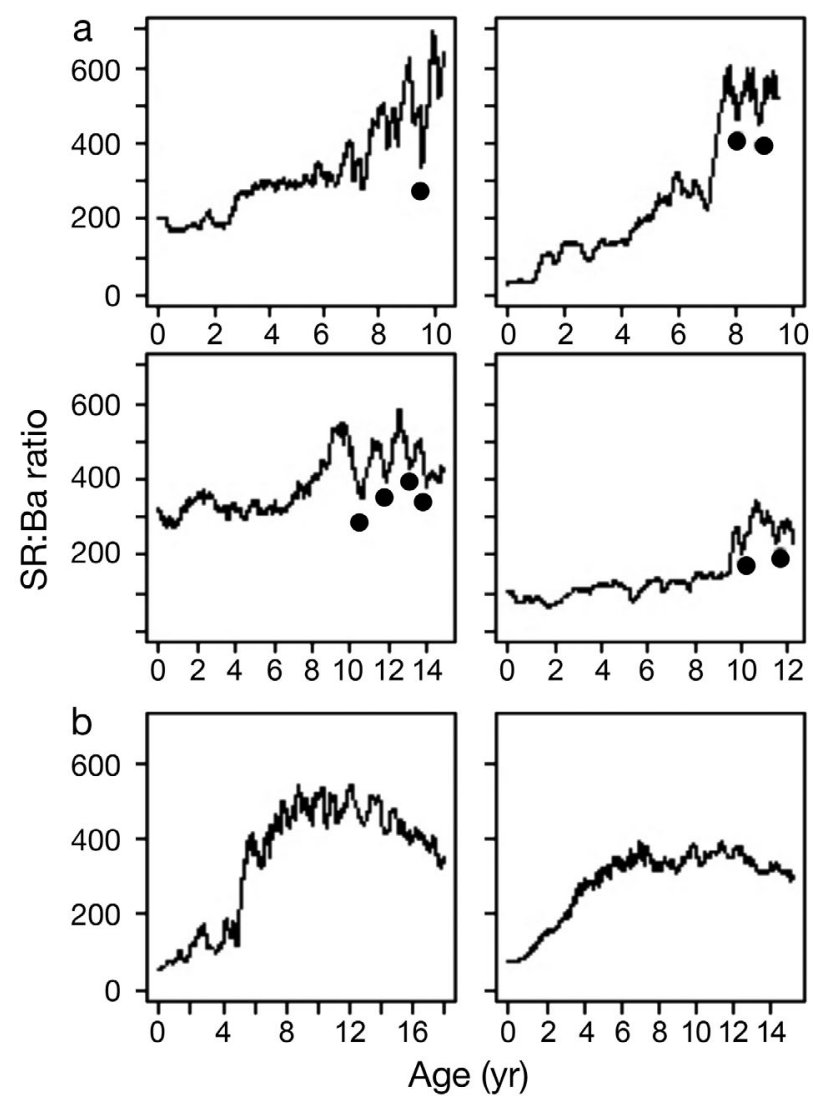

Fig. 4. Carcharhinus leucas. Typical plots of Sr:Ba ratio vs. age (yr) of individual (a) female and (b) male bull sharks. Dots in (a) indicate potential return of females to less saline waters

Table 2. Carcharhinus leucas. Average squared distance (standard deviation) between adult birth bands, females during postulated return periods to nurseries, and nurseries defined by juvenile bull sharks

\begin{tabular}{|lcc|}
\hline & Adult birth bands & Returns \\
\hline Fitzroy & $17.20(6.11)$ & $22.52(8.62)$ \\
Daly & $17.44(5.88)$ & $23.25(9.67)$ \\
Liverpool & $19.86(5.36)$ & $26.34(8.68)$ \\
East Alligator & $14.68(5.84)$ & $18.23(7.42)$ \\
Roper & $12.79(7.33)$ & $18.85(9.93)$ \\
Towns & $9.32(5.83)$ & $12.11(10.58)$ \\
Returns & $5.89(3.41)$ & - \\
\hline
\end{tabular}

net cps ratios were subtle, ranging between 100 and 200 , and their frequency did not increase with age. Any declines in Sr:Ba ratios were commonly within the $5 \%$ variation attributable to instrument drift.

Similarly oscillations in element:Ca ratios were evident in some elements (e.g. 0.025 to 0.01 for ${ }^{55} \mathrm{Mn}$ ), although predominately within the $5 \%$ variation attributable to instrument drift (see Fig. S3 in the supplement). Due to the absence of unique nursery fingerprints, and the lack of a distinctive nursery phase in
Table 3. Carcharhinus amboinensis. Pairwise ANOSIM correlations among pig-eye shark nurseries indicating whether differences are due to distinct environmental signatures or random variation. $R$-values ranging from $\sim 0$ (no difference) to 1 (highly different) are above the diagonal; p-values indicating probability of differences arising purely at random are below the diagonal. WA: Western Australia, NT: Northern Territories, N QLD: north Queensland. Sample sizes for each nursery are given

\begin{tabular}{|lccc|}
\hline & WA $(\mathrm{n}=16)$ & $\mathrm{NT}(\mathrm{n}=27)$ & $\mathrm{N}$ QLD $(\mathrm{n}=6)$ \\
\hline WA & - & 0.125 & 0.146 \\
NT & 0.070 & - & 0.078 \\
N QLD & 0.120 & 0.222 & - \\
\hline
\end{tabular}

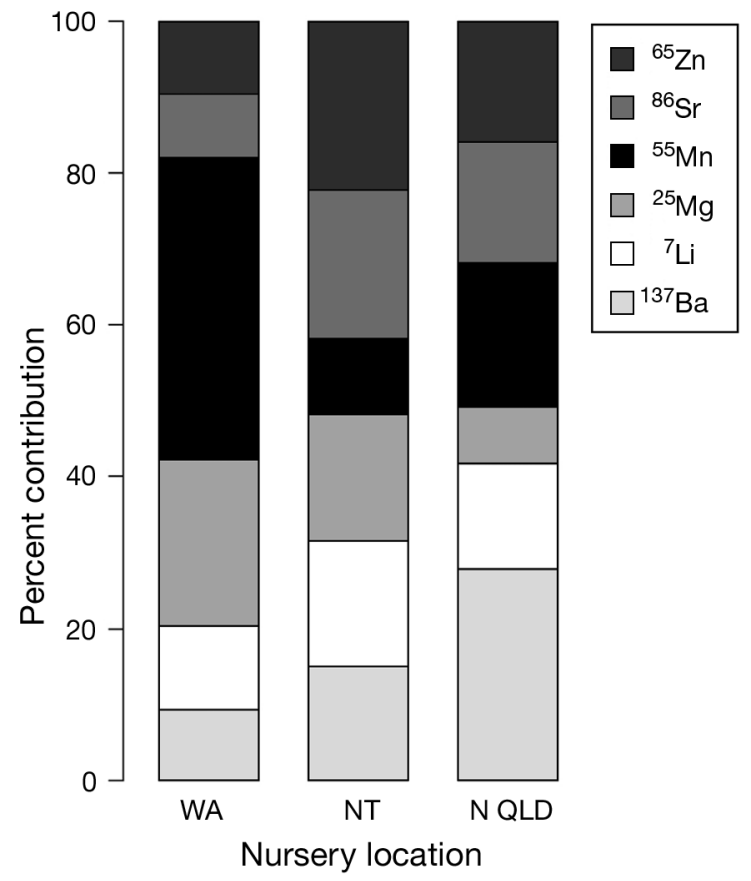

Fig. 5. Carcharhinus amboinensis. Similarity percentages (SIMPER) showing element contributions to pig-eye shark nursery signatures. Total $\mathrm{n}=49$; Western Australia (WA) $\mathrm{n}=$ 16; Northern Territories (NT) $\mathrm{n}=27$; north Queensland (N QLD) $\mathrm{n}=6$

element ratios, we did not attempt to identify chemical fingerprints of the juvenile phase within line scan analysis of adult pig-eye sharks.

\section{DISCUSSION}

Our results show the potential for chemical signatures within shark vertebrae to track the long-term (lifetime) movements of these animals within marine, estuarine and freshwater habitats. Unique elemental signatures between bull shark nurseries support the assumption that vertebral microchemistry reflects 
environmental signatures in some sharks. Declines in $\mathrm{Sr}: \mathrm{Ba}$ net cps ratios in mature female bull sharks are consistent with predicted changes in vertebral microchemistry reflecting periodic returns to freshwater nurseries assuming that $\mathrm{Sr}: \mathrm{Ba}$ net cps ratios reflect salinity changes as observed in other estuarine species (McCulloch et al. 2005, Allen et al. 2009). The lack of this pattern in male conspecifics suggests this behaviour might reflect pupping rather than mating events. This is further supported by the occurrence of this behaviour in 1 to 2 yr cycles correlating with the estimated 10 to 11 mo gestation period and rest year in the reproductive cycle (Last \& Stevens 2009).

Assuming vertebral signatures are not altered because of metabolic exchange in the vertebrae as the individual ages (Campana et al. 2002), none of the adults were born or resided in any of the nurseries identified from the analysis of the vertebrae of juveniles, and thus we could not confirm the existence of return to natal areas solely on the basis of evidence from chemical fingerprints. Unfortunately, comparisons between adult return events and their natal fingerprints lacked statistical power due to the limited numbers of return periods per individual. Furthermore, the relationship between body surface area and absorption of elements needs to be confirmed before robust conclusions between adult and juvenile life stages can be drawn.

Gradual declines in some element:Ca net cps ratios (e.g. 0.025 to 0.01 for ${ }^{55} \mathrm{Mn}$ ) in pig-eye sharks are consistent with adult conspecifics moving into deeper water away from nutrient-rich freshwater, particularly in areas such as northern Australia lacking nutrient upwellings. The lack of unique nursery signatures in juveniles prevented the identification of natal return behaviour in this species using vertebral microchemistry. Oceanic waters across northern Australia might not be chemically distinct due to mixing by oceanic and wind driven currents. In teleost fish, marine habitats can only be discriminated if there are large changes in water chemistry such as salinity, temperature or water gradients that are often present on narrower or more steeply sloping shelf systems (Gillanders \& Kingsford 2000, Kingsford et al. 2009, Steer et al. 2009). This might represent a limitation of vertebral microchemistry to discern movements in some shark species.

Age-specific variation in vertebral microchemistry also correlates with described changes in habitat use following the same assumptions. Sr:Ba net cps ratios were typically lowest in bull sharks around the time of birth, in accordance with neonates occupying freshwater environments. Ratios then increased at 2 to 4 yr of age as juveniles move into more saline waters, increasing net cps ratios until maturity. Adults showed the highest ratios, consistent with the consistent use of marine habitat (Yeiser et al. 2008, Heupel et al. 2010). Similar patterns in element:Ca net cps ratios in pig-eye sharks were not evident, again suggesting either a limitation of vertebral microchemistry to map fine-scale movements in sharks or that the use of nurseries is less defined in this species.

Surprisingly, vertebral microchemistry was more similar among juveniles and different among adult life stages between species than predicted. As expected, $\mathrm{Sr}$ :Ba net cps ratios of certain neonate stages of bull sharks were distinctly lower than equivalent pig-eye shark age classes, but other individuals were almost identical. This suggests a degree of habitat overlap between species as juveniles and highlights the individual variability among bull sharks. Furthermore, the greater variation in $\mathrm{Sr}$ :Ba net cps ratios in adult bull sharks might reflect the recently defined broad-scale movement patterns into cooler eastern and western Australian waters and the absence of such behaviour in pig-eye sharks (Brunnschweiler et al. 2010, Carlson et al. 2010).

The incorporation of elements within juvenile bull shark vertebrae highlights the potential for vertebral microchemistry as a valuable tool for discriminating complex behaviour such as pupping or natal site fidelity, although clarification of how elements are conserved in shark vertebrae, lag and cumulation effects, and whether these signatures are stable through time, are needed (Cailliet \& Radtke 1987, Welden et al. 1987). Results suggest chemical cues can guide female returns to nursery and as such, implies large consequences should water chemistry change due to altering freshwater flows, or drainage from surrounding industries.

Conclusively attributing specific behaviour to certain vertebral signatures is beyond the scope of this study, but because bull sharks inhabit a wide diversity of habitats with specific age-related patterns of habitat use, changes in vertebral microchemistry should correlate with this behaviour. Conversely, such habitat-shifting behaviour is not described in pig-eye sharks, leading to the expectation - and our observation - of relatively lower variation in vertebral microchemistry in this species. Current results highlight the potential for vertebral microchemistry to describe shark movements between chemically distinct environments; however, the power of this method will depend on clearer definition of the mineralisation process in shark vertebrae.

Acknowledgements. Funded by Tropical Rivers and Coastal Knowledge Research Hub, Charles Darwin University, Darwin and the Australian Institute of Marine Science. Sampling done with the support of fishermen, Wildlife Resources Inc., Kakadu National Park and the Department of Resources Fisheries, Northern Territory. 


\section{LITERATURE CITED}

Allen PJ, Hobbs JA, Cech JJ, Van Eenennaam JP, Doroshov SI (2009) Using trace elements in pectoral fin rays to assess life history movements in sturgeon: estimating age at initial seawater entry in Klamath River green sturgeon. Trans Am Fish Soc 138:240-250

Beamish RJ, McFarlane GA, King JR (2005) Migratory patterns of pelagic fishes and possible linkages between open ocean and coastal ecosystems off the Pacific coast of North America. Deep-Sea Res II 52:739-755

Branstetter S, Stiles R (1987) Age and growth-estimates of the bull shark, Carcharhinus leucas, from the northern Gulf of Mexico. Environ Biol Fishes 20:169-181

Brown RJ, Severin KP (2009) Otolith chemistry analyses indicate that water $\mathrm{Sr}: \mathrm{Ca}$ is the primary factor influencing otolith $\mathrm{Sr}: \mathrm{Ca}$ for freshwater and diadromous fish but not for marine fish. Can J Fish Aquat Sci 66:1790-1808

Brunnschweiler JM, Queiroz N, Sims DW (2010) Oceans apart? Short-term movements and behaviour of adult bull sharks Carcharhinus leucas in Atlantic and Pacific Oceans determined from pop-off satellite archival tagging. J Fish Biol 77:1343-1358

Cailliet GM, Goldman KJ (2004) Age determination and validation in chondrichthyan fishes. In: Carrier JC, Musick JA, Heithaus MR (eds) Biology of sharks and their relatives. CRC Press, Boca Raton, FL, p 399-448

Cailliet GM, Radtke RL (1987) A progress report on the electron microprobe analysis technique for age determination and verification in elasmobranchs. In: Summerfelt RC, Hall GE (eds) The age and growth of fish. The Iowa State University Press, Ames, IA, p 359-369

Campana SE (1999) Chemistry and composition of fish otoliths: pathways, mechanisms and applications. Mar Ecol Prog Ser 188:263-297

Campana SE (2001) Accuracy, precision and quality control in age determination, including a review of the use and abuse of age validation methods. J Fish Biol 59:197-242

> Campana SE, Natanson LJ, Myklevoll S (2002) Bomb dating and age determination of large pelagic sharks. Can J Fish Aquat Sci 59:450-455

Carlson JK, Ribera MM, Conrath CL, Heupel MR, Burgess GH (2010) Habitat use and movement patterns of bull sharks, Carcharhinus leucas determined using pop-up satellite archival tags. J Fish Biol 77:661-675

> Chapman MG, Underwood AJ (1999) Ecological patterns in multivariate assemblages: information and interpretation of negative values in ANOSIM tests. Mar Ecol Prog Ser 180:257-265

Clarke KR, Gorley RN (2001) PRIMERv5: user manual/tutorial PRIMER-E, Plymouth

> Clarke LM, Walther BD, Munch SB, Thorrold SR, Conover DO (2009) Chemical signatures in the otoliths of a coastal marine fish, Menidia menidia, from the northeastern United States: spatial and temporal differences. Mar Ecol Prog Ser 384:261-271

Crook DA, Gillanders BM (2006) Use of otolith chemical signatures to estimate carp recruitment sources in the mid-Murray River, Australia. River Res Appl 22:871-879

Dean MN, Summers AP (2006) Mineralized cartilage in the skeleton of chondrichthyan fishes. Zoology 109: 164-168

Field IC, Meekan MG, Buckworth RC, Bradshaw CJA (2009) Protein mining the world's oceans: Australasia as an example of illegal expansion-and-displacement fishing. Fish Fish 10:323-328

Gillanders BM (2005) Otolith chemistry to determine move- ments of diadromous and freshwater fish. Aquat Living Resour 18:291-300

Gillanders BM, Kingsford MJ (2000) Elemental fingerprints of otoliths of fish may distinguish estuarine 'nursery' habitats. Mar Ecol Prog Ser 201:273-286

Hale LF, Dudgeon JV, Mason AZ, Lowe CG (2006) Elemental signatures in the vertebral cartilage of the round stingray, Urobatis halleri, from Seal Beach, California. Environ Biol Fishes 77:317-325

Hays GC, Bradshaw CJA, James MC, Lovell P, Sims DW (2007) Why do Argos satellite tags deployed on marine animals stop transmitting? J Exp Mar Biol Ecol 349:52-60

Heithaus MR, Delius BK, Wirsing AJ, Dunphy-Daly MM (2009) Physical factors influencing the distribution of a top predator in a subtropical oligotrophic estuary. Limnol Oceanogr 54:472-482

Heupel MR, Simpfendorfer CA (2008) Movement and distribution of young bull sharks Carcharhinus leucas in a variable estuarine environment. Aquat Biol 1:277-289

> Heupel MR, Yeiser BG, Collins AB, Ortega L, Simpfendorfer CA (2010) Long-term presence and movement patterns of juvenile bull sharks, Carcharhinus leucas, in an estuarine river system. Mar Freshw Res 61:1-10

Hueter RE, Heupel MR, Heist EJ, Keeney DB (2005) Evidence of philopatry in sharks and implications for the management of shark fisheries. J Northw Atl Sci 35:239-247

> Kingsford MJ, Hughes JM, Patterson HM (2009) Otolith chemistry of the non-dispersing reef fish Acanthochromis polyacanthus: cross-shelf patterns from the central Great Barrier Reef. Mar Ecol Prog Ser 377:279-288

Knip DM, Heupel M, Simpfendorfer CA, Tobin AJ, Moloney J (2011) Ontogenetic shift in movement and habitat use for juvenile pigeye sharks Carcharhinus amboinensis in a tropical nearshore region. Mar Ecol Prog Ser 425:233-246

Kraus RT, Secor DH (2004) Incorporation of strontium into otoliths of an estuarine fish. J Exp Mar Biol Ecol 302: 85-106

Last PR, Stevens JD (2009) Sharks and rays of Australia, Vol 2. CSIRO Publishing, Melbourne

Martin GB, Thorrold SR (2005) Temperature and salinity effects on magnesium, manganese, and barium incorporation in otoliths of larval and early juvenile spot Leiostomus xanthurus. Mar Ecol Prog Ser 293:223-232

McCulloch M, Cappo M, Aumend J, Muller W (2005) Tracing the life history of individual barramundi using laser ablation MC-ICP-MS Sr-isotopic and $\mathrm{Sr} / \mathrm{Ba}$ ratios in otoliths. Mar Freshw Res 56:637-644

Milton DA, Chenery SR (2001) Sources and uptake of trace metals in otoliths of juvenile barramundi (Lates calcarifer). J Exp Mar Biol Ecol 264:47-65

Munksgaard NC, Antwertinger Y, Parry DL (2004) Laser ablation ICP-MS analysis of Faviidae corals for environmental monitoring of a tropical estuary. Environ Chem 1:188-196

> Myers RA, Baum JK, Shepherd TD, Powers SP, Peterson CH (2007) Cascading effects of the loss of apex predatory sharks from a coastal ocean. Science 315:1846-1850

Neer JA, Thompson BA, Carlson JK (2005) Age and growth of Carcharhinus leucas in the northern Gulf of Mexico: incorporating variability in size at birth. J Fish Biol 67:370-383

Ortega LA, Heupel MR, Van Beynen P, Motta PJ (2009) Movement patterns and water quality preferences of juvenile bull sharks (Carcharhinus leucas) in a Florida estuary. Environ Biol Fishes 84:361-373

Schindler DE, Essington TE, Kitchell JF, Boggs C, Hilborn R (2002) Sharks and tunas: fisheries impacts on predators with contrasting life histories. Ecol Appl 12:735-748 
Simpfendorfer CA, Heupel MR (2004) Assessing habitat use and movement. In: Carrier JC, Musick JA, Heithaus MR (eds) Biology of sharks of and their relatives. CRC Press, Boca Raton, FL, p 553-572

Simpfendorfer CA, Freitas GG, Wiley TR, Heupel MR (2005) Distribution and habitat partitioning of immature bull sharks (Carcharhinus leucas) in a southwest Florida estuary. Estuaries 28:78-85

Speed CW, Field IC, Meekan MJ, Bradshaw CJA (2010) Complexities of coastal shark movements and their implications for management. Mar Ecol Prog Ser 408:275-293

Steer MA, Fowler AJ, Gillanders BM (2009) Age-related movement patterns and population structuring in southern garfish, Hyporhamphus melanochir, inferred from otolith chemistry. Fish Manag Ecol 16:265-278

Thorburn D, Rowland AJ (2008) Juvenile bull sharks Carcharhinus leucas (Valenciennes, 1839) in northern Australian Rivers. The Beagle. Records of the Museums and Art Galleries of the Northern Territory 24:79-86

Tillett BJ, Meekan MJ, Field IC, Hua Q, Bradshaw CJA (2011a) Similar life-history traits in bull (Carcharhinus leuCas), and pig-eye (C. amboinensis) sharks. Mar Freshw Res 62:in press. doi:10.1071/MF10271

Editorial responsibility: Kenneth Sherman, Narragansett, Rhode Island, USA
Tillett BJ, Meekan MJ, Field I, Thorburn D, Ovenden J (2011b) Evidence for reproductive philopatry in the bull shark, Carcharhinus leucas in northern Australia. J Fish Biol (in press)

Van Achterbergh E, Ryan CG, Jackson SE, Griffin WL (2001) Mineralogical Association of Canada Short Course 29:239

- Voegeli FA, Smale MJ, Webber DM, Andrade Y, O'Dor RK (2001) Ultrasonic telemetry, tracking and automated monitoring technology for sharks. Environ Biol Fishes 60: $267-281$

> Walther BD, Thorrold SR (2006) Water, not food, contributes the majority of strontium and barium deposited in the otoliths of a marine fish. Mar Ecol Prog Ser 311:125-130

Welden BA, Cailliet GA, Flegal AR (1987) Comparison of radiometric with vertebral band age estimates in four California elasmobranchs. In: Summerfelt RC, Hall GE (eds) The age and growth of fish. Iowa State University Press, Ames, IA, p 301-315

Yeiser BG, Heupel MR, Simpfendorfer CA (2008) Occurrence, home range and movement patterns of juvenile bull (Carcharhinus leucas) and lemon (Negaprion brevirostris) sharks within a Florida estuary. Mar Freshw Res 59: 489-501

Submitted: December 28, 2010; Accepted: May 23, 2011 Proofs received from author(s): July 19, 2011 